\title{
Particleboards production from date palm biomass
}

\author{
Siham Amirou • Abdelatif Zerizer • \\ Antonio Pizzi · Imane Haddadou • Xiaojian Zhou
}

Received: 9 March 2013/Published online: 25 July 2013

(C) Springer-Verlag Berlin Heidelberg 2013

\begin{abstract}
Date palm biomass is a renewable natural resource that has not widely been utilized in industry. The objective of this study was to examine some chemical properties of date palm trunk and rachis (holocellulose, cellulose, lignin and extractives) and to evaluate their suitability to produce composite panels. Particleboards were produced using trunk and rachis as an alternative raw material for forest products industry in the presence of two types of polycondensation resins (phenol-formaldehyde and melamine urea-formaldehyde) which were selected as binding agents. The panels were tested for their physical (water absorption and thickness swelling) and mechanical (modulus of rupture, modulus of elasticity and internal bond strength) properties. The internal bond strength of date palm trunk and date palm rachis based boards met the requirements of the general purpose product standards (EN 312 ) at $0.70 \mathrm{~g} / \mathrm{cm}^{3}$ density. The panels made with phenolformaldehyde resin showed better performance with respect to the panels made with melamine urea-formaldehyde. In addition, the particleboard made with date palm trunk particles had better quality compared to the particleboard made from date palm rachis particles. Based on preliminary results of this work, raw materials from date palm trunks and rachis can have a promising potential in the manufacture of particleboards and as a substitute for wood in board production.
\end{abstract}

S. Amirou $(\bowtie) \cdot$ A. Zerizer · I. Haddadou

UR-MPE, FSI, UMBB, Independence Avenue of Boumerdes, 35000 Boumerdes, Algeria

e-mail: amirou.siham@gmail.com

A. Pizzi $\cdot$ X. Zhou

LERMAB, ENSTIB, University of Lorraine, Epinal, France

\section{Herstellung von Spanplatten aus Dattelpalmenbiomasse}

Zusammenfassung Die Biomasse der Dattelpalme ist ein natürlicher nachwachsender Rohstoff, dessen industrielle Nutzung noch nicht weit verbreitet ist. Ziel dieser Studie ist es, einige chemische Eigenschaften (Holocellulose, Cellulose, Lignin und Extraktstoffe) des Stamms und der Rhachis der Dattelpalme zu untersuchen und deren Eignung für die Herstellung von Verbundplatten zu beurteilen. Spanplatten wurden unter Verwendung von Stamm und Rhachis als alternativen Rohstoff für die Holzindustrie und zwei verschiedenen Polykondensationsharzen (Phenolformaldehyd und Melamin-Harnstoff-Formaldehyd) als Bindemittel hergestellt. Die physikalischen (Wasseraufnahme und Dickenquellung) sowie die mechanischen (Biegefestigkeit, Elastizitätsmodul und Querzugfestigkeit) Eigenschaften der Platten wurden geprüft. Die Querzugfestigkeit von Platten aus Spänen des Dattelpalmenstamms und der-rhachis mit einer Dichte von $0.70 \mathrm{~g} / \mathrm{cm}^{3}$ erfüllten die Anforderungen an Platten für allgemeine Zwecke gemäß EN 312. Die mit Phenolformaldehyd hergestellten Platten wiesen bessere Eigenschaften auf als die mit Melamin-Harnstoff-Formaldehydharz hergestellten Platten. Die mit Spänen aus dem Stamm der Dattelpalme hergestellten Platten erwiesen sich als besser als die mit Spänen aus der Rhachis hergestellten Platten. Basierend auf diesen vorläufigen Ergebnissen lässt sich sagen, dass Rohstoffe aus dem Stamm und der Rhachis von Dattelpalmenholz ein vielversprechendes Ersatzmaterial für die Plattenherstellung sein könnte.

\section{Introduction}

Date palm (Phoenix dactylifera L.) is one of the oldest fruit crop cultivated in arid areas of the Middle-East and North- 
Africa. It has always played an important role in the economic and social life of the people of these regions. It presents a source of income to oases inhabitants, provides protection to under-crops from the harshness of the climate and reduces the damage from sand storms and wind erosion (Mohamed Ahmed et al. 2011).

In 2006, world production of dates was about 7 million tons and the top 10 producing countries were Egypt, Saudi Arabia, Iran, United Arab Emirates, Pakistan, Algeria, Sudan, Oman, Libya, and Tunisia (Raj 2010).

In Algeria the production has nearly doubled in the last decade. The date palm grove areas in Algeria has registered a significant expansion, estimated at $69 \%$, rising from 101,000 ha in 2000 to 169361 ha in 2009 with a total of 18.7 million palm trees scattered over around 100,000 farms (Abdouche 2010).

Annually, it is estimated that at least 150 million tons of solid wood is used in wood-based industries in Algeria. Therefore, wood-based industries must find alternative sources of local raw materials. Date palm biomass currently appears to be the most viable alternative in this regard.

The date palm industry in Algeria, with its 169,361 ha of plantation, produced over 7.8 million tons of dates and approximately 25 million tons of biomass annually. The biomass from date palm residue includes the date palm trunks, date palm petioles, leaves and bunches (Fig. 1). Unfortunately these materials are not used very effectively; open burning and land filling are common practices to eliminate date palm residue which cause environmental pollution and put adverse impact on the ecosystem. Meanwhile, aging palms is a factor that should not be neglected as $30 \%$ of Algerian palms are above production age (Messar 1996). So there is an abundance of date palm trunk that can be exploited. The residue, which resembles rice husk to a great extent, is especially promising in future wood-based industries. Crisis of wood shortage also makes this resource a potential substitute for wood due to its abundant availability.

Panelboards are generally manufactured from wood particles bonded strongly using synthetic polymeric adhesives or other similar binders. The processing includes pressing under heat for sufficient time to allow the adhesive to bind the waste material through the curing process. Iskanderani (2008) used date palm midrib residues in particleboard manufacture and tried to use the best manufacturing conditions to get acceptable quality requirements from such raw material. Results have proven that the products from palm midribs carry physical and mechanical properties satisfying international standards.

Currently, information on the properties of particleboard made from date palm trunk and rachis (brunches) bonded with different adhesives are still very limited.

The aim of this study, therefore, was to evaluate the physic-mechanical properties of particleboards fabricated

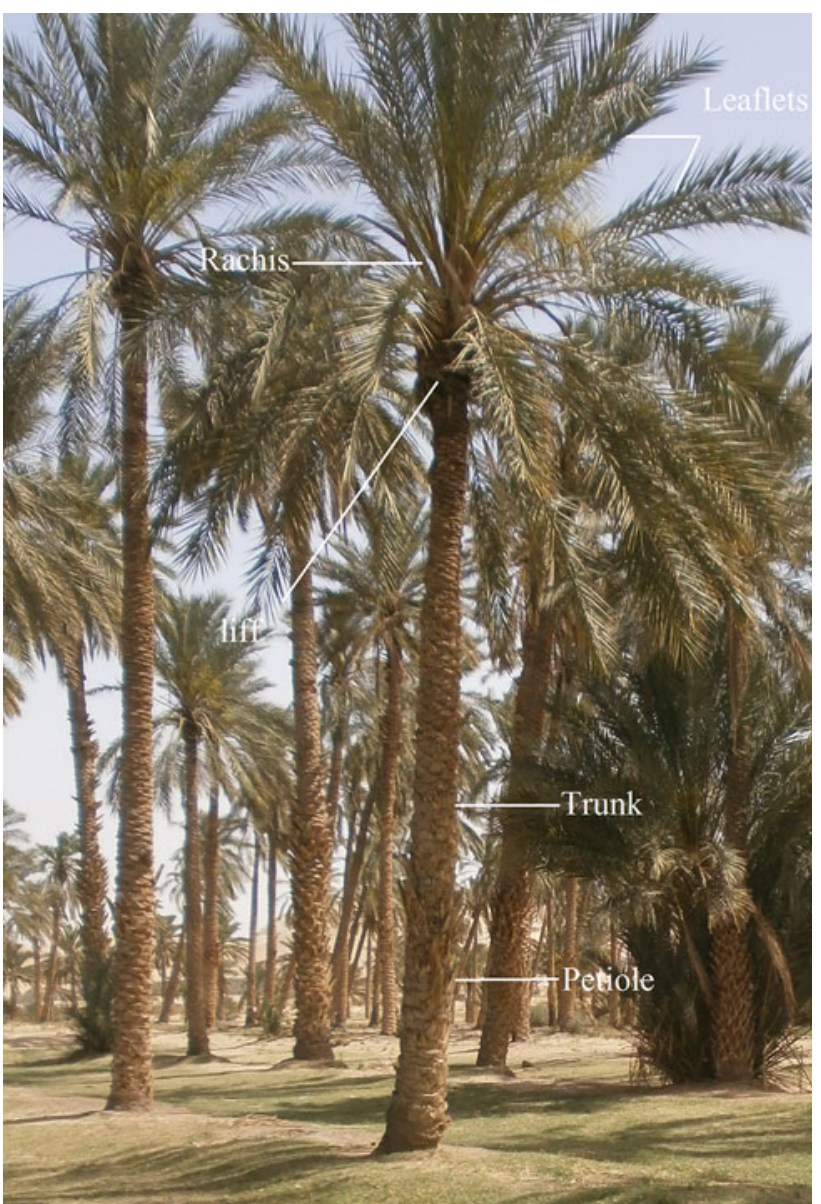

Fig. 1 Date palm tree Abb. 1 Dattelpalme

from date palm trunk and rachis with the aid of phenol formaldehyde (PF) and melamine urea formaldehyde (MUF) adhesives (binding agents). This study seeks collecting preliminary data on the use of date palm residues of Algeria for particleboard manufacture. The study is also focused on evaluating the strength properties [modulus of rupture (MOR), modulus of elasticity (MOE), and internal bond strength (IB)] and responses of the boards to water uptake and thickness swelling (TS). This information is required prior to the commercialization of these residues as valueadded products. This will additionally help to develop productive uses for date palm trunk and rachis, mitigating environmental problems from waste biomass while also developing an alternative and cheap material to wood.

\section{Materials and methods}

\subsection{Sample collection and preparation}

Date palm biomass in the form of trunks and rachis was obtained from a local plantation in southern Algeria. Two 
types of materials, trunks and bark particles, were produced from the trunks; only trunk particles are used to manufacture particleboard. Rachis (branch) was also cut from the trees. These different residual types were reduced to a particle size of $1-2 \mathrm{~cm}$ in a laboratory-type mill PALLMANN. Eventually, the particles were oven dried at $100{ }^{\circ} \mathrm{C}$ to reach a target moisture content of almost $3 \%$.

\subsection{Determination of the chemical composition of the raw materials}

Specimens of trunk and branches (rachis) of date palm were obtained and prepared according to TAPPI T $257 \mathrm{~cm}$ 02 (2002) standard for the determination of their chemical composition.

Holocellulose and cellulose contents were determined according to the method of Wise and Murphy (1946). Lignin content was determined based on the Klason method (TAPPI 222 om-02) (2002). Extractives were determined according to TAPPI T 204 cm-97 (1997).

\subsection{Synthesis of PF resin}

Ninety-four parts by mass of phenol were mixed with 40 parts (20/80) of methanol/water solution and 55 parts by mass of $96 \%$ paraformaldehyde powder. After stirring for $30 \mathrm{~min}$ at $40^{\circ} \mathrm{C}$, the temperature was increased over a period of $30 \mathrm{~min}$ to reflux $\left(94^{\circ} \mathrm{C}\right)$. A total of 20 parts by mass of sodium hydroxide solution (33\%) was added in four equal parts at 15 min intervals over the previous total of $60 \mathrm{~min}$. The mixture was kept at reflux for additional $30 \mathrm{~min}$ and was then cooled immediately.

\subsection{Synthesis of MUF resin}

$348 \mathrm{~g}$ urea formaldehyde concentrate (UFC) (comprising $57 \%$ formaldehyde, $23 \%$ urea and $20 \%$ water) was added to $90 \mathrm{~g}$ water and $46.8 \mathrm{~g}$ urea under continuous mechanical stirring in a glass reactor equipped with a reflux condenser and thermometer. Then, the $\mathrm{pH}$ of solution was set at 10-10.5. The temperature was increased to $92^{\circ} \mathrm{C}$ and the reaction continued for additional $30 \mathrm{~min}$. The $\mathrm{pH}$ was then adjusted to 5.0-5.5 by addition of a $10 \%$ formic acid solution. After $1 \mathrm{~h}$, the $\mathrm{pH}$ was brought to 9.5 or higher using $33 \% \mathrm{NaOH}$ aqueous solutions. $123 \mathrm{~g}$ melamine and $57 \mathrm{~g}$ water were added to the reaction mixture. The reaction was kept for $20 \mathrm{~min}$, then $19.5 \mathrm{~g}$ urea was added to the reaction mixture and the $\mathrm{pH}$ was adjusted again to 9.5. When the water tolerance reached 400 or $170 \%$, the resin was cooled and the $\mathrm{pH}$ of the solution was set at 9.5 before finally storing at room temperature.
2.5 Production of particulate panels

The chips were placed in a drum blender and sprayed with phenol formaldehyde (PF) or melamine-urea formaldehyde (MUF) for $1 \mathrm{~min}$ to obtain a homogenized mixture. The resin loading of solids was $10 \%$ based on dry particle content. The properties of the adhesives [phenol formaldehyde (PF) and melamine urea-formaldehyde (MUF)] used in this study are given in Table 1.

Panels were produced at a target density of $0.70 \mathrm{~g} / \mathrm{cm}^{3}$. About $960 \mathrm{~g}$ of the wet particles was used for each panel. The experimental design of the single-layer panels (particleboards) is summarized in Table 2. Experiments were conducted for trunk and rachis based particleboards to evaluate the impacts of each resin type (PF and MUF).

The intended dimensions of the produced particleboards were $350 \times 300 \times 14 \mathrm{~mm}^{3}$ before pressing and after edge trimming the final dimensions of the particleboards were $320 \times 270 \times 14 \mathrm{~mm}^{3}$. The total press time was maintained at $7.5 \mathrm{~min}$ whereas the press temperature was held at $195{ }^{\circ} \mathrm{C}$.

The physical properties, water absorption and thickness swelling (EN 317) (1993) and mechanical properties, modulus of rupture (EN 310) (1993), modulus of elasticity (EN 310) (1993) and internal bond strength (EN 319) (1993) were also determined for the produced particleboards. The panels were produced in triplicates from each group. Nine specimens were used to determine the modulus of elasticity and modulus of rupture (MOR), and for the internal bond strength (IB), thickness swelling (TS), and water absorption, twenty specimens were used for each of them. Average values were taken for each parameter in each case. Test samples for thickness swelling and water absorption were prepared from samples that have formerly been tested for modulus of rupture and elasticity.

\section{Results and discussion}

\subsection{Chemical composition}

Table 3 presents the chemical composition of date palm trunk and date palm rachis used.

Table 1 Properties of adhesives used

Tab. 1 Spezifikation der verwendeten Klebstoffe

\begin{tabular}{lll}
\hline Properties & PF & MUF \\
\hline Solid $(\%)$ & 60 & 61 \\
Density $\left(\mathrm{g} / \mathrm{cm}^{3}\right)$ & 1.18 & 1.13 \\
$\mathrm{pH}$ & 10.75 & 9.5 \\
Viscosity (cps) & 330 & 224 \\
\hline
\end{tabular}


Table 2 Experimental design used in the study

Tab. 2 Versuchsplan

\begin{tabular}{lll}
\hline Panel type & Composition & $\begin{array}{l}\text { Number } \\
\text { of panels }\end{array}$ \\
\hline A & $100 \%$ Trunk particles with PF (TPF) & 3 \\
B & $100 \%$ Trunk particles with MUF (TMUF) & 3 \\
C & $100 \%$ Rachis particles with PF (RPF) & 3 \\
D & $100 \%$ Rachis particles With MUF (RMUF) & 3 \\
\hline
\end{tabular}

Table 3 Chemical composition of trunk and rachis

Tab. 3 Chemische Zusammensetzung von Stamm und Rhachis

\begin{tabular}{lllll}
\hline $\begin{array}{l}\text { Part of } \\
\text { date palm }\end{array}$ & $\begin{array}{l}\text { Holocellulose } \\
(\%)\end{array}$ & $\begin{array}{l}\text { Alpha } \\
\text { cellulose } \\
(\%)\end{array}$ & $\begin{array}{l}\text { Lignin } \\
(\%)\end{array}$ & $\begin{array}{l}\text { Extractives } \\
(\%)\end{array}$ \\
\hline Trunk & $81.84(0.10)$ & $43.7(0.21)$ & $16.94(0.12)$ & $1.22(0.06)$ \\
Rachis & $64.45(0.14)$ & $35.87(0.18)$ & $26.89(0.13)$ & $8.66(0.02)$ \\
\hline
\end{tabular}

Values in parenthesis are standard deviations

Date palm is a lignocellulosic material that contains a high level of holocellulose. The oil palm has also been reported to have a high holocellulose content of $82.4 \mathrm{wt} \%$ (Mohamad Ibrahim et al. 2011). The cellulose was in the range of $43.7 \mathrm{wt} \%$ for date palm trunk and $35.87 \mathrm{wt} \%$ for date palm rachis. In the same way, the amounts of holocellulose and cellulose for the two raw materials were similar to those found in wood and non-wood plants. The obtained data show that date palm rachis is characterized by relatively high amounts of lignin $(26.89 \mathrm{wt} \%)$. The date palm trunk had the lowest extractive content of about $1.22 \mathrm{wt} \%$, while date palm rachis had high amounts of extractives. These contents also agree with previously reported contents for chemical composition of date palm raw material (Khiari et al. 2010; Khristova et al. 2005; El Morsy 1980; Nasser and Al-Mefarrej 2011). Therefore, the chemical composition of date palm biomass should not pose any problems for the manufacture of composite panels.

\subsection{Mechanical properties}

Results of the mechanical properties of particleboards made from date palm trunk and date palm rachis are presented in Figs. 2, 3 and 4 and in Table 4.

According to EN 312 (2005), 11.5 and $13.0 \mathrm{~N} / \mathrm{mm}^{2}$ are the minimum requirements for MOR of particleboard panels for general uses and interior fitments (including furniture), respectively, while the minimum MOE for interior fitments is $1,600 \mathrm{~N} / \mathrm{mm}^{2}$.

MOR and MOE of the particleboards produced using trunk particles bonded with $\mathrm{PF}$ resin rose to 18.01 and

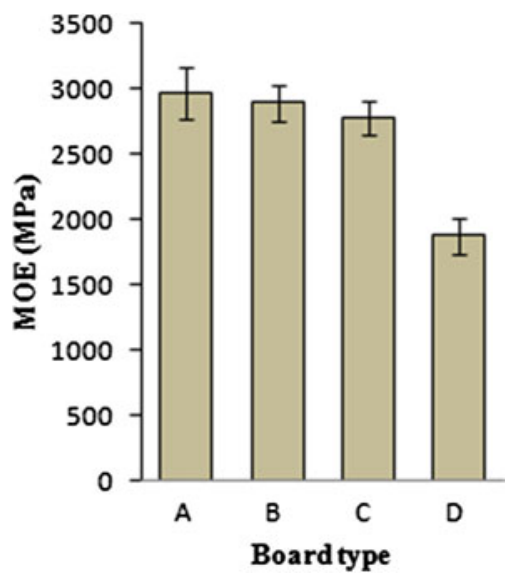

Fig. 2 Comparison of the MOE values of manufactured boards Abb. 2 Vergleich des Elastizitätsmoduls der hergestellten Platten

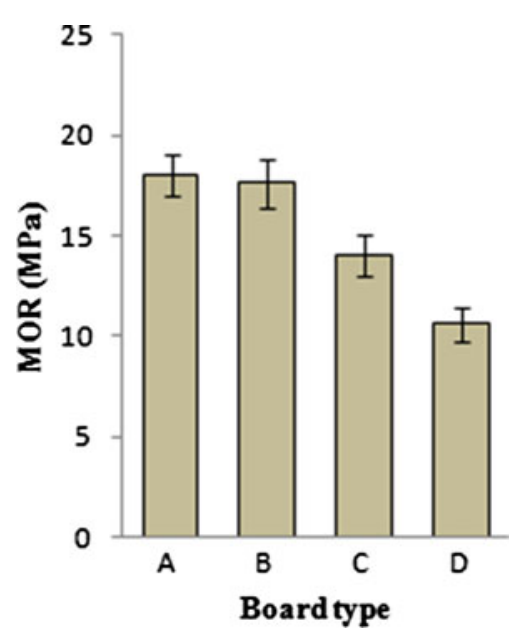

Fig. 3 Comparison of the MOR values of manufactured boards Abb. 3 Vergleich der Biegefestigkeit der hergestellten Platten

2974.23 MPa, respectively. The lowest MOR (10.6 MPa) and MOE (1876.7 MPa) values were determined for panels type D using MUF-bonded particleboards.

Panel types A, B and C comply with the minimum MOR requirements for general purpose use and interior fitments including furniture manufacture in EN 312 Standard while this was not the case for type D panels. Thus, average MOE values of the different panel types met the minimum requirements for general purpose use and interior fitments including furniture manufacture of the EN Standard. Compared with MUF particleboard, the PF based particleboards had higher MOE, IB and MOR. The results indicated that PF had better compatibility with the date palm trunk and date palm rachis than MUF.

The internal bond (IB) strengths of the produced particleboards varied from 0.64 to $0.95 \mathrm{~N} / \mathrm{mm}^{2}$. The minimum requirement according to EN 312 is $0.24 \mathrm{~N} / \mathrm{mm}^{2}$ for 


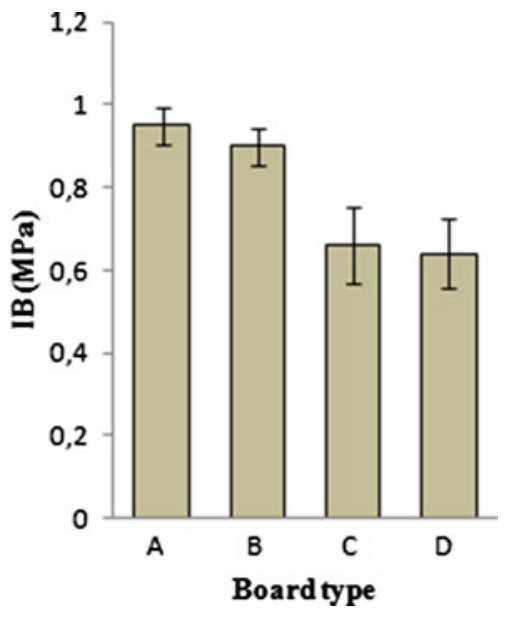

Fig. 4 Comparison of the IB values of manufactured panels Abb. 4 Vergleich der Querzugfestigkeit der hergestellten Platten

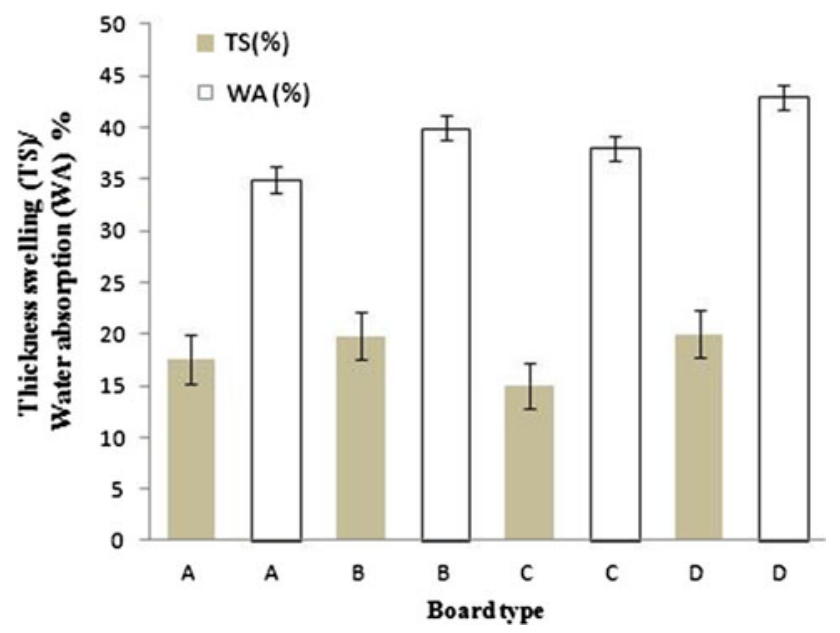

Fig. 5 Thickness swelling and water absorption of the prepared panels

Abb. 5 Dickenquellung und Wasseraufnahme der hergestellten Platten

general purpose, $0.35 \mathrm{~N} / \mathrm{mm}^{2}$ for interior fitments and for load-bearing boards, and $0.50 \mathrm{~N} / \mathrm{mm}^{2}$ for heavy-duty load bearing boards.
All produced panels met the requirements for general purpose and interior fitments including furniture manufacture stated in EN 312 standard.

Compared with the date palm rachis particleboard, the date palm trunk particleboard had significantly higher MOE, IB and MOR. According to Nemli et al. (2009), this result may be explained by the highest lignin and extractives contents, and much lower cellulose as well as holocellulose contents of date palm rachis than that of date palm trunk. Further, higher lignin content increases the brittleness of the lignocellulosic material, on the contrary to the cellulose which decreases the brittleness (Nemli et al. 2009).

Ashori and Nourbakhsh (2008) produced particleboards with date palm wood and urea-formaldehyde resin $(9,10$, $11 \%$ dry weight basis), using a board density of $0.75 \mathrm{~g} /$ $\mathrm{cm}^{3}$, resulting in MOR, MOE and IB values in the range of 10-16.6, 1,333-1,861, and 0.38-0.63 MPa, respectively. In addition, Hegazy and Aref (2010) produced particleboards with date palm midribs and $10 \%$ urea-formaldehyde resin and obtained MOR, MOE and IB values of 13.34, 2,018 and $0.53 \mathrm{MPa}$, respectively. Thus, it appears that the particleboards produced with date palm trunk and rachis in the presence of two types of polycondensation resins (phenolformaldehyde and melamine urea -formaldehyde) exhibited analogous and sometimes even better performance than that obtained by other authors using urea-formaldehyde adhesive.

\subsection{Physical properties}

Based on EN 312, the maximum thickness swelling (TS) requirement after $24 \mathrm{~h}$ immersion in water is $15 \%$. TS percentages after $24 \mathrm{~h}$ was higher than the TS-EN 312 requirement $(15 \%)$ for all boards produced in this study, except for panel type $\mathrm{C}$ panel as shown in Fig. 5 and Table 4. This could be attributed to the absence of a suitable water repellent component within the formulation during the board production or due to lack of sufficient intermolecular forces between the binder and the cellulosic material. A maximum TS value of $15 \%$ is allowed for

Table 4 Physical and mechanical properties of the test panels

Tab. 4 Physikalische und mechanische Eigenschaften der untersuchten Platten

\begin{tabular}{lllllll}
\hline & Density $\left(\mathrm{g} / \mathrm{cm}^{3}\right)$ & MOE $(\mathrm{MPa})$ & MOR $(\mathrm{MPa})$ & IB strength $($ dry $)(\mathrm{MPa})$ & TS 24H $(\%)$ & WA 24H $(\%)$ \\
\hline A TPF & 0.70 & $2970(194)$ & $18.0(1.06)$ & $0.95(0.046)$ & $17.6(2.36)$ & $35(1.28)$ \\
B TMUF & 0.70 & $2890(135)$ & $17.6(1.20)$ & $0.90(0.046)$ & $19.8(2.32)$ & $40(1.20)$ \\
C RPF & 0.70 & $2780(132)$ & $14.0(1.05)$ & $0.66(0.091)$ & $14.9(2.18)$ & $38(1.24)$ \\
D RMUF & 0.70 & $1880(135)$ & $10.6(0.85)$ & $0.64(0.085)$ & $20.0(2.30)$ & $43(1.19)$ \\
\hline
\end{tabular}

Values in parenthesis are standard deviations

MOR modulus of rupture, MOE modulus of elasticity, IB internal bond, TS thickness swelling, WA water absorption 
particleboard panels used in load-bearing applications under dry conditions. High mean thickness swelling percentages observed for the particleboards could be explained by the higher number of water attractive $\mathrm{OH}$ groups in the material. The holocellulose contains hydroxyl groups which possess high hydrophilicity that enable high water absorption whereas lignin is known to be totally amorphous and hydrophobic thus does not absorb water (Nourbakhsh et al. 2011). This means in total that a significant amount of $\mathrm{OH}$ groups were not involved in the polycondensation process which may be related to their inaccessibility to the used resin or the amount of employed resin was not enough to cope with most of the reactive hydroxyl groups.

The boards produced with phenol formaldehyde (PF) resin showed high resistance to water penetration resulting in lower swelling values. This can be easily explained by the fact that phenol formaldehyde itself is known to be resistant to water even at elevated temperatures (Guler and Ozen 2004).

Higher thickness swelling percentages for crop based particleboards were therefore comparable which can be listed as follows: for tobacco straw $25 \%$ (Kalaycioğlu 1992), for cotton carpel $22 \%$ (Alma et al. 2005).

The test results of water absorption after $24 \mathrm{~h}$ soaking in water showed that the PF particleboards had better qualities than the MUF particleboards (Fig. 5). The long-term water absorption of PF particleboard was about $12 \%$ lower than that of MUF particleboard and maintained relatively stable dimensions. Panels produced using particles of rachis mixtures absorbed higher amounts of water compared to trunk particle mixtures. Differences in water absorption may be attributable to the chemical composition (Stone and Scallan 1965), specific surface area (Ziegler 1974), pressing temperature and time and particle size (Iskanderani 2008).

\section{Conclusion}

As a consequence of the increasing consumption of wood and wood based materials due to the tremendous increase in world population, maximum gain must be obtained from natural sources. Date palm trunk and rachis, a residue produced in huge amounts in Algeria; show promising potential for manufacturing particleboards or related materials.

The results obtained in this study indicate that the manufacture of particleboards from trunk and rachis wastes alone by using PF or MUF adhesives is technically feasible.

Using unexploited date palm biomass for manufacturing particleboards would be a good solution due to the shortage of raw materials in the Algerian particleboard industry sector.

The mechanical evaluations revealed that PF and MUFbonded particleboards produced at $0.70 \mathrm{~g} / \mathrm{cm}^{3}$ density with $10 \%$ resin complied with the minimum requirements of the designated standards for general grade particleboards, except for TS and WA due to the lack of hydrophobic additives in the used formulations in these panels. However, this problem may be easily solved by the addition of paraffin to the boards.

MUF-bonded particleboards resulted in lower bending and internal bond strength values. The results also showed that the cellulose content of date palm trunk had a positive correlation with all the mechanical properties while the lignin content of date palm rachis had a remarkably inverse correlation (Nemli et al. 2009).

This study suggests that date palm trunk and date palm rachis are superior with respect to other agricultural residues in terms of mechanical properties. Future studies on optimum conditions of particle geometry, adhesion and pressing conditions are needed to improve the panel quality, especially their dimensional stability.

Using renewable materials like date palm trunk and rachis for manufacturing particleboards could contribute to reduce the shortage of raw materials for particleboard industry as well as diminishing environmental problems regarding their burning. In addition, the pressure on other forest resources can be greatly reduced and more job opportunities can be created.

\section{References}

Abdouche F (2010) Communication from the botanic unit development at the ministry of agriculture and rural developmentAlgeria. Algerian Press Service, APS, Algiers

Alma MH, Kalaycioğlu H, Bektas I, Tutus A (2005) Properties of cotton carpel-based particleboards. Ind Crops Prod 22(8):141149

Ashori A, Nourbakhsh A (2008) Effect of press cycle time and resin content on physical and mechanical properties of particleboard panels made from the underutilized low-quality raw materials. Ind Crops Prod 28:225-230

El Morsy MMS (1980) Studies on the rachis of Egyptian date palm leaves for hardboard production. Fibre Sci Technol 13(4):317321

EN 310 (1993) Wood based panels-determination of modulus of elasticity in bending strength. CEN-European Committee for Standardization

EN 317 (1993) Particleboards-determination of swelling in thickness after immersing in water. $\mathrm{CEN}$-European Committee for Standardization

EN 319 (1993) Particleboards-determination of tensile strength perpendicular to the plane of the board. CEN-European Committee for Standardization

EN 312 (2005) Particleboards-specifications. European Committee for Standardization, Brussels (Belgium) 
Guler C, Ozen R (2004) Some properties of particleboards made from cotton stalks (Gossypium hirsitum L.). Holz Roh Werkst 62:4043

Hegazy SS, Aref IM (2010) Suitability of some fast-growing trees and date palm fronds for particleboard production. For Prod J 60(7/8): 599-604

Iskanderani FI (2008) Physical properties of particleboard panels manufactured from phoenix dactylifera-L (date palm) mid-rib chips using ureaformaldehyde binder. Int J Polym Mater 57(10): 979-995

Kalaycioğlu H (1992) Utilization of annual plant residues in production of particleboard. ORENKO-92. First national forest product congress, Trabzon, Turkey, pp 288-292

Khiari R, Mhenni MF, Belgacem MN, Mauret E (2010) Chemical composition and pulping of date palm rachis and Posidonia oceanica-a comparison with other wood and non-wood fibre sources. Bioresource Technol 101:775-780

Khristova P, Kordsachia O, Khider T (2005) Alkaline pulping with additives of date palm rachis and leaves from Sudan. Bioresource Techno 96:79-85

Messar EM (1996) The Algerian date sector: situation and prospects on the horizon 2010. Options méditerranéennes 28:23-44

Mohamad Ibrahim MN, Zakaria N, Sipaut CS, Sulaiman O, Hashim R (2011) Chemical and thermal properties of lignins from oil palm biomass as a substitute for phenol in a phenol formaldehyde resin production. Carbohyd Polym 86:112-119

Mohamed Ahmed MVO, Bouna ZEO, Mohamed Lemine FM, Djeha TKO, Trifi M, Mohamed Salem AO (2011) Use of multivariate analysis to assess phenotypic diversity of date palm (Phoenix dactylifera L.) cultivars. Sci Hort-Amst 127:367-371

Nasser RA, Al-Mefarrej HA (2011) Midribs of date palm as a raw material for wood-cement composite industry in Saudi Arabia. J Appl Sci Res 15(12):1651-1658

Nemli G, Demirel S, Gumuokaya E, Aslan M, Acar C (2009) Feasibility of incorporating waste grass clippings (Lolium perenne L.) in particleboard composites. Waste Manag 29:1129-1131

Nourbakhsh A, Farhani Baghlani F, Ashori A (2011) Nano-SiO ${ }_{2}$ filled rice husk/polypropylene composites: physico-mechanical properties. Ind Crops Prod 33:183-187

Raj BR (2010) Date palm cultivation in the changing scenario of Indian arid zones: challenges and prospects. In: Desert plants: biology and biotechnology, vol 4, pp 423-459. doi:10.1007/9783-642-02550-1_20

Stone JE, Scallan AM (1965) The effect of component removal upon the porous structure of the cell wall of wood. J Polym Sci Pol Sym 11:13-25

TAPPI T $204 \mathrm{~cm}-97$ (1997) Solvent extractives of wood and pulp

TAPPI 222 om-02 (2002) Acid insoluble lignin in wood and pulp

TAPPI T $257 \mathrm{~cm}-02$ (2002) Sampling and preparing wood for analysis

Wise LE, Murphy M (1946) A Chlorite holocellulose, its fractionation and bearing on summative wood analysis and studies on the hemicelluloses. Paper Trade J 122:35-43

Ziegler GA (1974) Water vapor sorption by softwood cell wall constituents. $\mathrm{PhD}$ thesis, The Pennsylvania State University, Agricultural, Forestry and Wildlife 